\title{
SPECIMEN RECORDS AND SIGHTINGS OF ANCIENT MURRELETS FROM THE CANADIAN PRAIRIE PROVINCES
}

SPENCER G. SEALY, Department of Zoology, University of Manitoba, Winnipeg, MB R3T 2N2; HARRY R. CARTER, United States Geological Survey, Biological Resources Division, 6924 Tremont Road, Dixon, CA 95620 and Department of Wildlife, Humboldt State University, Arcata, CA 95521; and JOCELYN HUDON, Provincial Museum of Alberta, 12845-102 Avenue, Edmonton, AB T5N OM6

\section{Introduction}

The Ancient Murrelet is one of the most vagrant-prone species in the avian family Alcidae, the auks. ${ }^{10}$ Ancient Murrelets nest on both sides of the North Pacific Ocean, from China to Russia, and Alaska to British Columbia. ${ }^{1,23}$ Individuals occasionally occur in the interior of North America, sometimes thousands of kilometres from the Pacific Ocean. Since the early 1880 s, nearly 100 records of the Ancient Murrelet have been reported at localities across Canada and the United States, ${ }^{15,18,19,24}$ and one individual was present for several months off the coast of Great Britain. ${ }^{25}$ Eight of these records are from the prairie provinces of Canada: five from Alberta ( 2 specimens, 3 sightings), one sighting from Saskatchewan, and two specimens from Manitoba. Four of the records are documented here, new information is provided for the other four, and the circumstances surrounding the occurrences of Ancient Murrelets in this region are examined. The records are detailed below in chronological order. Their numbers correspond to the location of recovery or sighting shown in Fig. 1. The specimens are housed in the collections of the Manitoba Museum of Man and Nature (MMMN) and the Provincial Museum of Alberta (PMA).

\section{Specimens and Sight Records}

1. 8 October 1953 (MMMN 2252): A bird was found by W. Sutherland dying on a street in the Winnipeg suburb of St. James, Manitoba. ${ }^{16,24}$ The emaciated specimen was collected by the late A.G. Lawrence and presented to the Manitoba Museum of Man and Nature. Not sexed, the bird is in juvenal plumage, i.e. hatching-year (Fig. 2, upper), with new remiges (flight feathers) and contour feathers and no white crest feathers on the crown. Insect damage to the secondaries, wing coverts (particularly on the right wing), and feathers of the rump of this specimen should not be interpreted as extreme feather wear.

\section{2. "Autumn" 1975 (MMMN 1.2-3398):}

Manitoba's second specimen was a hatching-year female (Fig. 2, lower) that drowned in a commercial fishing net set offshore near Pine Dock on the west side of Lake Winnipeg." Collected by Dave Stevens (or Stephens), the bird's remiges and contour feathers are new and there are no white crest feathers 
Figure 1. Locations of specimens collected and sightings recorded of Ancient Murrelets in Alberta, Saskatchewan, and Manitoba. Numbers correspond to the description of the record given in the text.

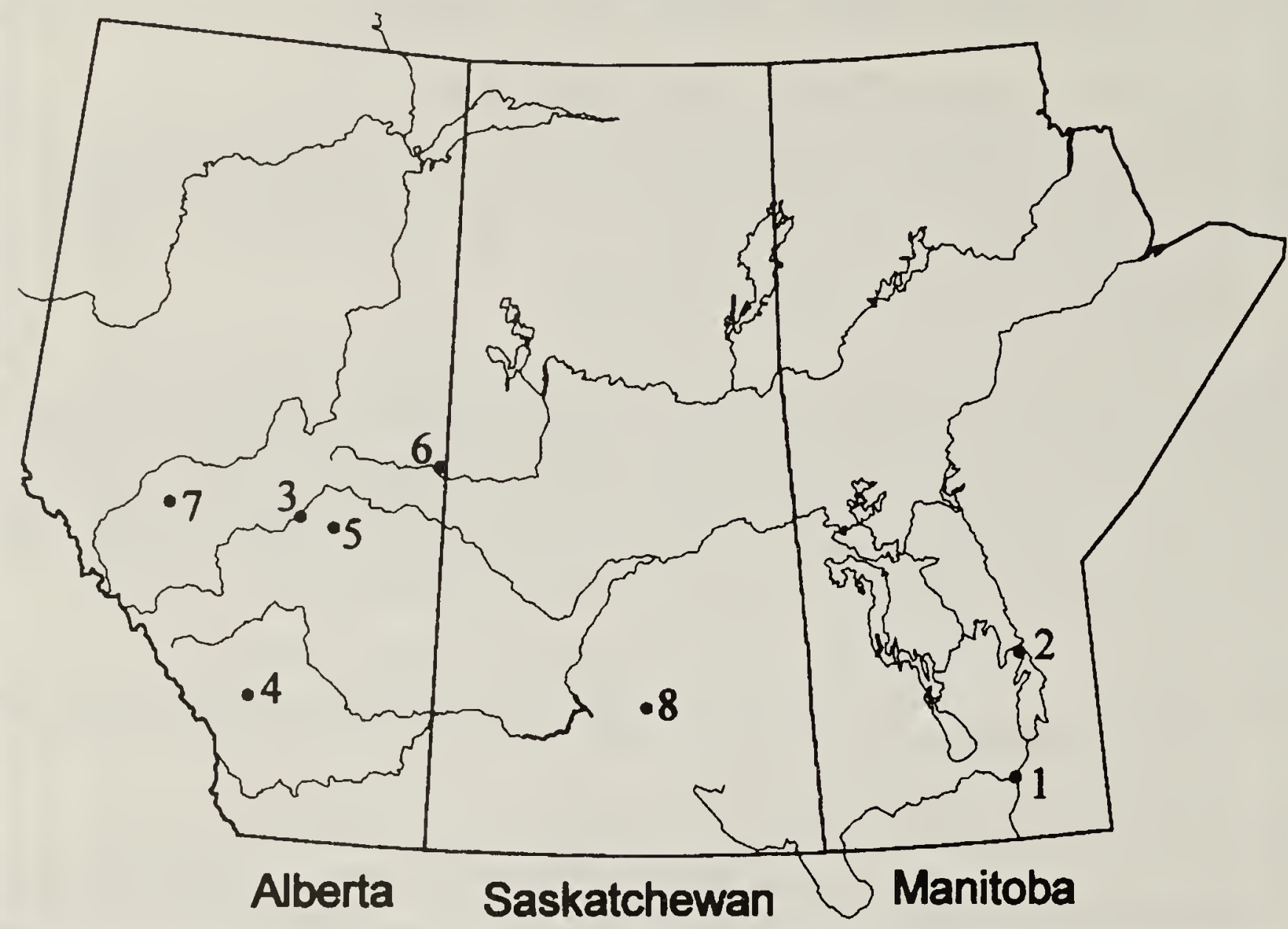

visible on the crown. The bird, including fish remains in its digestive tract, weighed $234.5 \mathrm{~g}$, a total mass about 25 $\mathrm{g}$ higher than the mean breedingseason weights of adults ${ }^{17}$ and recently fledged juveniles, ${ }^{20}$ but close to the mean weight of adults in late fall. ${ }^{9}$ This bird may have survived for some time on Lake Winnipeg or another body of fresh water. The brown tipped feathers on the shoulders, sides and flanks, typical of juveniles shortly after the "atsea" rearing period from July through September, ${ }^{8}$ had worn off. This suggests the bird was captured toward the end of September, or later.

\section{25 October 1975 (PMA Z75.92.1):} An Ancient Murrelet was captured on the shore of the North Saskatchewan River, about $400 \mathrm{~m}$ west of the Clover Bar landfill in Edmonton, Alberta, and died a few hours later. It was deposited in the Provincial Museum of Alberta. ${ }^{26}$ The bird was a male in breeding (alternate) plumage (Fig. 3, lower), but with a few white feathers interspersed among the black feathers of the chin and throat. A few minute white crest feathers are visible above and behind the eyes. Body mass was $122 \mathrm{~g}$, which is about $75 \mathrm{~g}$ below the mean mass of breeding adults. ${ }^{17}$

4. 17-20 October 1982: The first of three sight records in Alberta was made on the Glenmore Reservoir near Calgary. ${ }^{27}$ It was noted (p. 49) that "the bird seemed in good health, flying back and forth to other locations on the reservoir hundreds of metres away. It also dived..., occasionally surfacing with a small fish in its bill."27 The bird cannot be aged with certainty from the three published photographs, ${ }^{12,27}$ but the dark feathers apparently restricted to the chin and white throat suggest it was in juvenal plumage. This condition is supported 


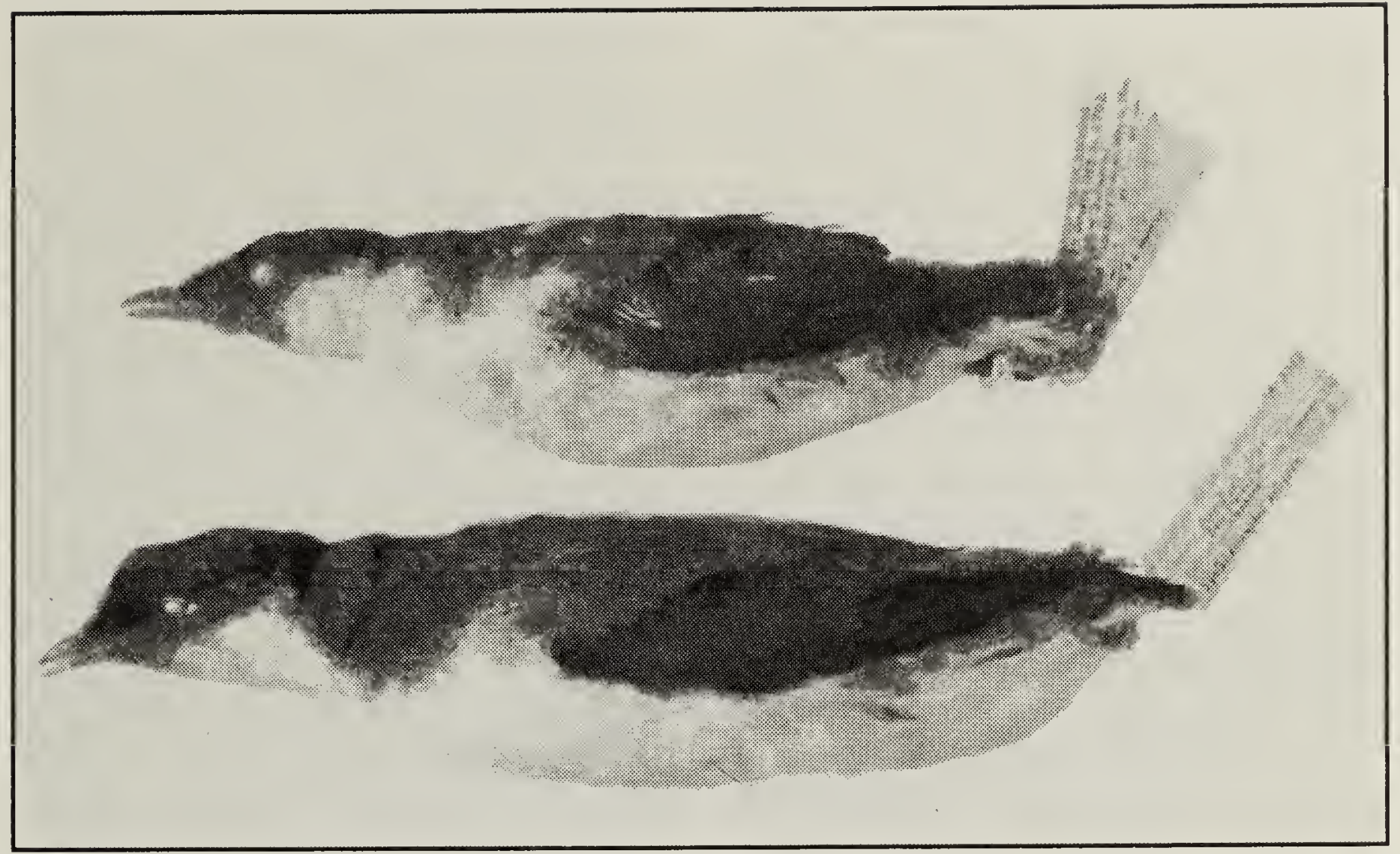

Figure 2. Ancient Murrelet specimens from Manitoba: upper-juvenile, unsexed, Winnipeg, 8 October 1953 (MMMN 2252, originally 2702); lower-juvenile female, Lake Winnipeg, autumn, 1975 (MMMN 1.2-3398). (Note: the difference in size of the specimens is an artifact of preparation.)

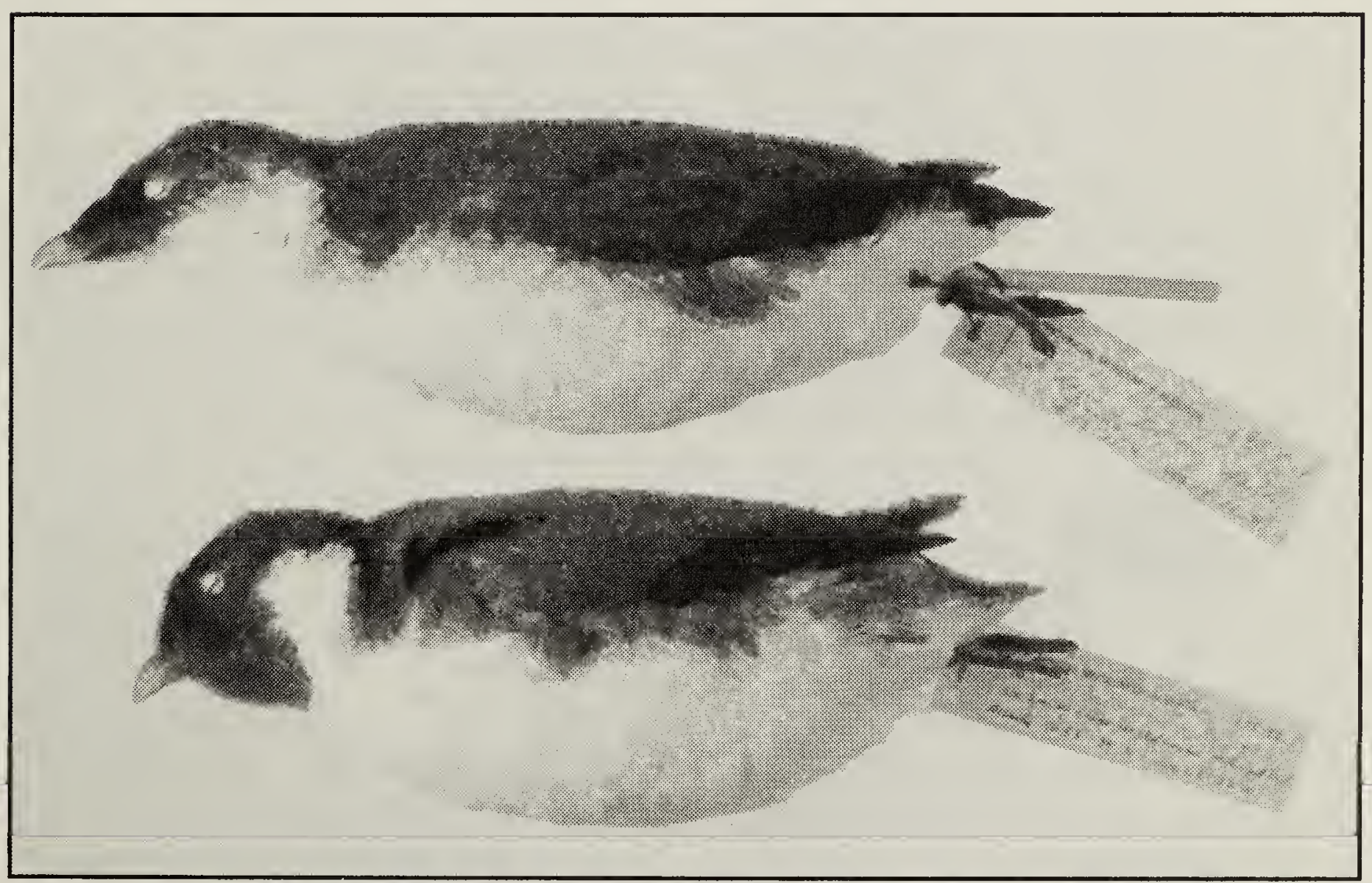

Figure 3. Ancient Murrelet specimens from Alberta: upper-juvenile female, Edson, 29 September 1994 (PMA Z95.5.1); lower-adult male, North Saskatchewan River, 25 October 1975 (PMA Z75.92.1). 
by a detailed field description of the bird filed at the Provincial Museum of Alberta by Doug Collister and John B. Steeves (S. Holohan, letter 15 January 1983), accompanied by Steeves' field sketch (Fig. 4), which shows a dark chin and white throat. Also filed at the PMA were three other descriptions of the bird made from about $15 \mathrm{~m}$ away, submitted by Victor Maltby, Stuart Johnston (accompanied by a sketch), and A. C. Slater. Johnston's description and sketch, and Maltby's description indicated a dark chin and white throat, whereas Slater did not note the colour of these regions.

\section{2 October 1983: Dick Dekker} recorded a single bird at several places on Beaverhill Lake, east of Edmonton, Alberta. ${ }^{4}$ It was identified as it flew by many times, albeit at considerable distances. Eventually, the bird was observed from $15 \mathrm{~m}$ to $30 \mathrm{~m}$ away. In addition to features of the plumage, bill and feet, Dekker noted the black chin and throat, which suggests an after- hatching-year plumage. The bird dived frequently and appeared to be in good condition.

6. 18 September 1988: For about two hours, Richard Klauke observed and videotaped an Ancient Murrelet at Centre Bay on Cold Lake, Cold Lake Provincial Park, near the AlbertaSaskatchewan border. Klauke reported to Jocelyn Hudon that the bird "dived repeatedly". The limited extent of black on the throat, although not clearly visible in Fig. 5, suggests a juvenile.

\section{29 September 1994 (PMA Z95.5.1):}

A hatching-year female was found dead at Edson, Alberta, in the eastern foothills of the Rocky Mountains. The plumage is new and unworn. A few minute white crest feathers are visible above and behind the eyes (Fig. 3 , upper). Feathers on the shoulders and sides are tipped with brown. The bird weighed $144.5 \mathrm{~g}$, which is about $55 \mathrm{~g}$ below that of recently independent juveniles. ${ }^{20}$

Figure 4. Sketch of Ancient Murrelet observed on Glenmore Reservoir near Calgary, 17-20 October 1982; the white throat is evident (sketch by John B. Steeves).

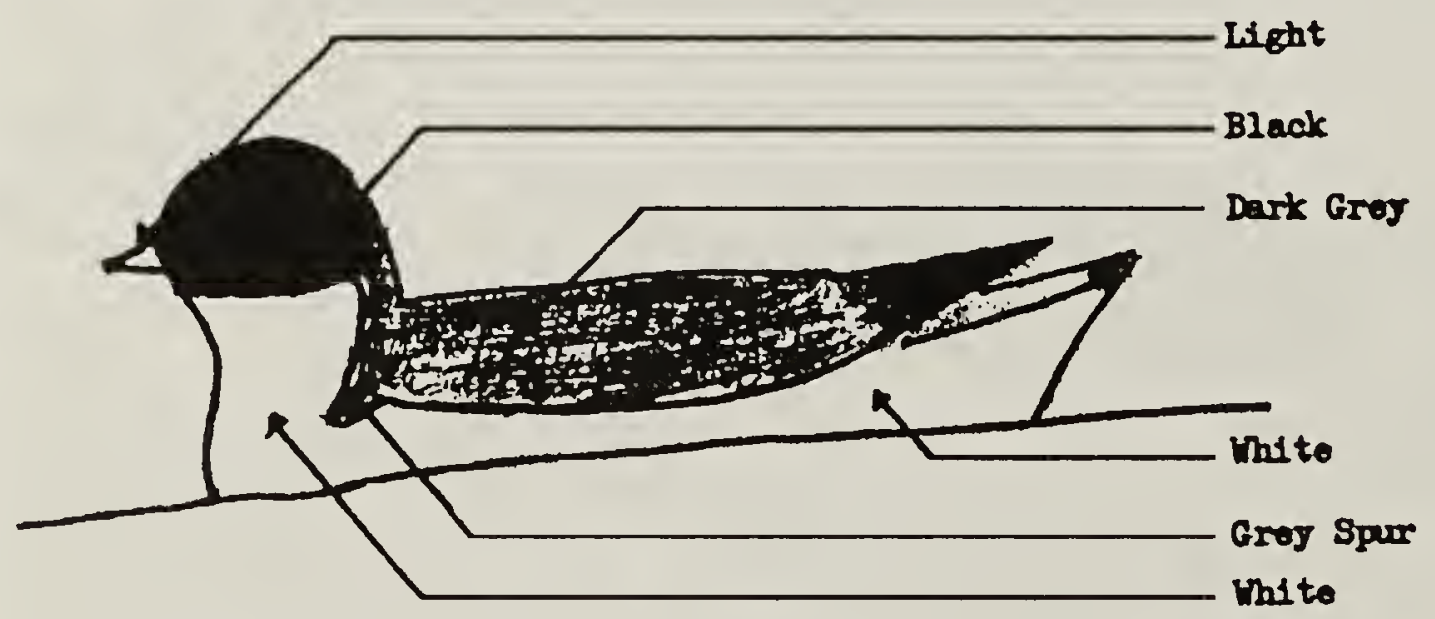

\section{UTDERVING}

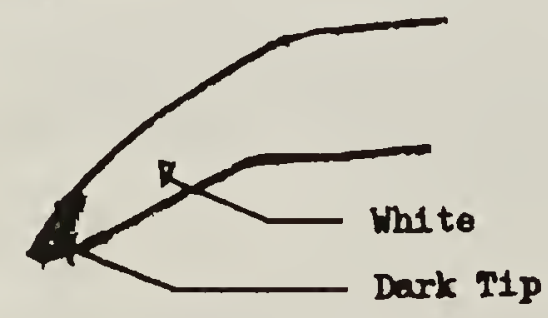

TAIL RDCIOA

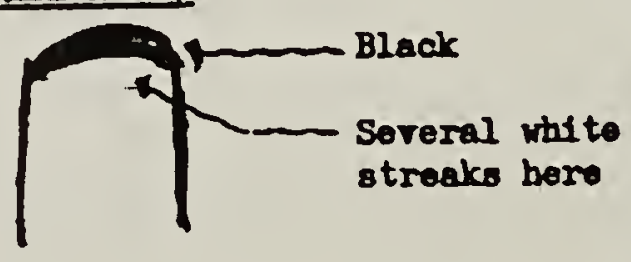




\section{Figure 5. Ancient Murrelet observed on 18 September 1988 at Centre Bay, Cold Lake, Alberta (photograph by Richard Klauke).}

\section{13 November 1998: A single bird} was observed by Bob Kreba and Curtis Pollock at Last Mountain Lake, Saskatchewan. ${ }^{13}$ Kreba suspected the bird was an immature (p. 47) "...based on the restricted amount of black on the chin." This is the first record of the Ancient Murrelet for the province of Saskatchewan, but because there is no specimen, identifiable photograph, or recognizable tape recording, the species will be regarded as of hypothetical occurrence.

\section{Discussion}

\section{The vagrants}

The recovery of the first specimen (no. 3 ) and the third sighting (no. 5) from Alberta are two of the few after-hatchingyear Ancient Murrelets recorded in the interior of North America. ${ }^{18,19}$ The other records from the Canadian prairie provinces were or were suspected of being juveniles, as were most of the other Ancient Murrelets recorded inland. ${ }^{19}$ Juveniles have outnumbered adults in other samples of seabirds that have moved beyond the normal limits of their ranges. Most of the hundreds of Thick-billed Murres collected during periodic incursions into the Great Lakes region between 1890 and 1952 were juveniles. ${ }^{7}$ Each of these movements involved large numbers of birds, whereas the movements inland of Ancient Murrelets generally have involved individuals. $15,19,24$

Post-breeding movements and timing of vagrancy

In coastal British Columbia, adult Ancient Murrelets accompanied by their newly hatched chicks, leave their nesting colonies in late May and June, and rear the chicks at sea for several weeks. ${ }^{6,17}$ Young are first seen alone in July. ${ }^{20}$ Numbers begin building up south of the breeding colonies, from Vancouver Island to coastal California, in late October and early November. ${ }^{2,9}$ This suggests that many individuals move southward well after nesting, after the molt is complete. But the whereabouts of the birds prior to this, while they are molting, and flightless, is a mystery. A.J. Gaston speculated that after the breeding season Ancient Murrelets may be carried by offshore currents from the Queen Charlotte Islands northwestward into the Gulf of Alaska, and a northward dispersal at this time may be a regular part of the annual schedule of Ancient Murrelets. ${ }^{8}$ Whether some or all of these birds would winter in the Gulf of Alaska, or eventually move south to Vancouver Island and the coastal waters of the United States is conjecture.

Vagrancy of Ancient Murrelets generally coincides with the movements to wintering areas in late summer and fall, and possibly also with movements away from these areas in spring. ${ }^{15,24}$ 
Occurrences in the Canadian prairie provinces have been recorded from 18 September (record no. 6 above) to 13 November (no. 8); two records (no. 2 and no. 3) were from 1975. The October 8 date of the 1953 Manitoba specimen (no. 1) was considered unusually early compared to other records reported before that year from the interior of North America. ${ }^{16}$ Indeed, most inland occurrences known to 1966 fell into two periods, late October-November and March. 15,18,19,24 This trend has continued since 1966, but other specimens and sightings have been recorded inland in August and September, including the sighting from Cold Lake on 18 September (no. 6) and specimens from British Columbia, Idaho, and Washington. ${ }^{3,5}$

\section{Origin of vagrants}

E.D. Munyer believed that during spring and fall migrations some Ancient Murrelets drifted southeast as a result of strong northwesterly winds coupled with conditions of poor visibility along the coast. ${ }^{15}$ The eight records from the Canadian prairie provinces suggest such eastward movements, which may have been related to specific weather encountered en route. Indeed, the 1975 Alberta and Manitoba records (no. 3 and no. 2 on Fig. 1) form nearly a straight line from west to east. Strong westerly winds apparently preceded the bird's arrival in Alberta, ${ }^{26}$ but the date of arrival of the bird in Manitoba is not known precisely.

Ancient Murrelets found in the interior of North America may have travelled from distant breeding areas in western Alaska or even Asia, although the largest breeding populations occur in the Queen Charlotte Islands, off the mainland coast of British Columbia. ${ }^{23}$ Long-distance movements of another alcid, the Long-billed Murrelet, from the northeast coast of Asia to the coast and interior of North America, have been recorded regularly since the late 1970 s, but still it is debated whether these movements were associated with anomalous weather patterns, the Aleutian Low, and/or EI Niño or La Niña conditions. 14,21,22 Occurrences of Ancient Murrelets in the interior of North America, on the other hand, date back more than 100 years, although the number of records, particularly sightings, has increased in recent decades. ${ }^{19}$ Continued scrutiny of sightings and recovery of specimens of Ancient Murrelets and other seabirds, in the interior of North America and elsewhere, should clarify patterns of vagrancy.

\section{Acknowledgements}

Herb Copland, Jack Dubois, and Janis Klapecki provided support and information, and loaned specimens under their care in the Manitoba Museum of Man and Nature. Rob Barrow photographed the specimens. Stuart Holohan provided a copy of a description and sketch by Dr. John B. Steeves of the Ancient Murrelet observed in Alberta, in 1982. Steeves permitted his sketch to be reproduced. Richard Klauke provided a photograph and details of his unpublished sight record from Alberta (deposited in the Provincial Museum of Alberta), and Bob Kreba (Royal Saskatchewan Museum, Regina) provided additional details of the sighting in Saskatchewan. We thank A. J. Gaston and an anonymous reviewer for technical and editorial comments on the manuscript. This work was supported by grants to S. G. Sealy from the Natural Sciences and Engineering Research Council of Canada.

1. American Ornithologists' Union. 1998. Check-list of North American Birds, 7th edition. American Ornithologists' Union, Washington, D.C. 
2. Ainley, D.G. 1976. The occurrence of seabirds in the coastal region of California. Western Birds 7:33-68.

3. Cannings, R.A., R.J. Cannings, and S.G. Cannings. 1987. Birds of the Okanagan Valley, British Columbia, Royal British Columbia Museum, Victoria.

4. Dekker, D. 1984. Ancient Murrelet at Beaverhill Lake. Alberta Naturalist 14:98.

5. Dobler, F. C., and T. W. Sauve. 1982. Ancient Murrelet on the Columbia River near Wenatchee, Washington. Murrelet 63:71-72.

6. Duncan, D. C., and A. J. Gaston. 1990. Movements of Ancient Murrelet broods away from a colony. Pp. 109-113. In: Sealy, S.G. (ed.). Auks at Sea. Studies in Avian Biology, Number 14.

7. Gaston, A. J. 1988. The mystery of the murres: Thick-billed Murres, Uria lomvia, in the Great Lakes region, 18901986. Canadian Field-Naturalist 102:705-711.

8. Gaston, A. J. 1994. Ancient Murrelet (Synthliboramphus antiquus). In: Poole, A. and F. Gill (eds.). The Birds of North America, No. 132. Philadelphia: The Academy of Natural Sciences; Washington, D.C.: The American Ornithologists' Union.

9. Gaston, A. J., H. R. Carter, and S. G. Sealy. 1993. Winter ecology and diet of Ancient Murrelets off Victoria, British Columbia. Canadian Journal of Zoology 71:64-70.

10. Gaston, A. J., and I. L. Jones. 1998. The Auks. Oxford University Press, Oxford.
11. Godfrey, W. E. 1986. The Birds of Canada, revised edition. National Museums of Canada, Ottawa.

12. Harris, W. C. 1983. Prairie provinces region. American Birds 37:192-194.

13. Kreba, R. 1999. Ancient Murrelet at Last Mountain Lake, Saskatchewan. Birders Journal 8:45-47.

14. Mlodinow, S. G. 1997. The Longbilled Murrelet (Brachyramphus perdix) in North America. Birding 29:461-475.

15. Munyer, E. D. 1965. Inland wanderings of the Ancient Murrelet. Wilson Bulletin 77:235-242.

16. Nero, R. W. 1968. Manitoba Black Guillemot specimen. Blue Jay 26:14-15.

17. Sealy, S. G. 1976. Biology of nesting Ancient Murrelets. Condor 78:294-306.

18. Sealy, S. G., and H. R. Carter. 1980. Inland Ancient Murrelets: an update (Abstract). Pacific Seabird Group Bulletin 7:57.

19. Sealy, S. G., and H. R. Carter. Vagrancy in the Ancient Murrelet: timing and preponderance of juvenile females. Review in preparation.

20. Sealy, S. G., and R. W. Campbell. 1979. Post-hatching movements of young Ancient Murrelets. Western Birds 10:25-30.

21. Sealy, S. G., H. R. Carter, and D. Alison. 1982. Occurrences of the Asiatic Marbled Murrelet [Brachyramphus marmoratus perdix (Pallas)] in North America. Auk 99:778-781.

22. Sealy, S. G., H. R. Carter, W. D. Shuford, K. D. Powers, and C. A. Chase III. 1991. Long-distance vagrancy of the Asiatic Marbled Murrelet in North 
America, 1979-1989. Western Birds 22:145-155.

23. Springer, A. M., A. Y. Kondratyev, H. Ogi, Y. V. Shibaev, and G. B. van Vliet. 1993. Status, ecology, and conservation of Synthliboramphus murrelets and auklets. In: Vermeer, K., Briggs, K. T., Morgan, K. H. and Seigel-Causey, D. (eds.). The Status, Ecology, and Conservation of Marine Birds of the North Pacific. Canadian Wildlife Service Special Publication, Ottawa. Pp. 187201.
24. Verbeek, N. A. M. 1966. Wanderings of the Ancient Murrelet: some additional comments. Condor 68:510-511.

25. Waldon, J. 1994. Ancient Murrelet in Devon: new to the Western Palearctic. British Birds 87:307-310.

26. Weseloh, D. V., and L. K. Weseloh. 1978. First record of the Ancient Murrelet for Alberta. Canadian Field-Naturalist 92:200-201.

27. Wisely, A. M. 1983. Ancient Murrelet in Calgary. Alberta Naturalist 13:49-50.

\section{POWER POLES ASSIST RANGE EXPANSION OF OSPREYS IN SASKATCHEWAN}

C. STUART HOUSTON, 863 University Drive, Saskatoon, SK S7N 0J8, and FRANK SCOTT, Box 2, GS 317, Saskatoon, SK S7K 3J6

In eastern North America, Ospreys have built nests on man-made platforms, towers, and duck-hunting blinds since at least $1881 .{ }^{3}$ Use of power utility structures is much more recent. ${ }^{5}$ In southern Ontario, wooden double cross-arm poles appeared as early as 1915; there was then a 57-year lag before Ospreys built nests on such poles in the Georgian Bay region, starting with one nest on a pole in 1972 and increasing to nests on 12 poles in $1989 .{ }^{2}$ By 1980 every Canadian province except Quebec and Saskatchewan had recorded such events. ${ }^{1,3}$ In Oregon, there was a 20-year lag between building of power poles for electric irrigation pumps and their use by
Ospreys; use then increased by leaps and bounds, from 1 pole in 1977 to 66 in 1993. ${ }^{3}$

This paper describes the extension of Osprey breeding range south from boreal forest lakes, their common habitat across most of Canada, into aspen parkland in Saskatchewan. In the late 1980s, Ospreys began to build nests on power poles near Murray and Jackfish lakes, and in 1998 nests were built at two places where power lines crossed the South Saskatchewan river. Power line poles appear to have facilitated both these range extensions and have led to local increases in the Osprey population. 